\title{
Fragment docking supported by NMR shift perturbations
}

\author{
Tim ten Brink ${ }^{*}$, Clementine Aguirre, Isabelle Krimm \\ From 9th German Conference on Chemoinformatics \\ Fulda, Germany. 10-12 November 2013
}

Fragment-based approaches have become popular tool in drug design due to their ability to screen large portions of chemical space with comparatively small libraries. However fragments can exhibit unspecific binding and even if they bind to a specific binding site in some cases more than one binding mode is observed [1]. For computational approaches like molecular docking fragments pose also new challenges. Score differences between different binding modes generated by docking are often small, making the identification of the correct, natural binding mode difficult.

The sensitivity of a nuclei's NMR chemical shift to changes in its chemical environment can be used to measure chemical shift perturbations (CSP) of protein atoms upon ligand binding. Especially ${ }^{1} \mathrm{H}$ and ${ }^{15} \mathrm{~N}$ CSP are easily obtainable from ${ }^{15} \mathrm{~N}$ HSQC spectra and can be used as probe for ligand orientation but also include information about conformational changes on the protein side. CSP data has been used to orientated drug like molecules into protein binding sites $[2,3]$ and can be included into the scoring function to improve docking [4].

Here we show how CSP can be used to quickly validate docking poses of smaller fragments by filtering them for their agreement between experimental CSP and simulated CSP for the docked poses. Additionally a more detailed analysis of the differences between the experimental and the simulated CSP profiles can be used to highlight protein regions and even single residues which undergo structural changes upon fragment binding.

Published: 11 March 2014

\footnotetext{
* Correspondence: tim.ten-brink@univ-lyon1.fr Institute des Sciences Analytiques - CNRS UMR5280, Universite Claude Bernard - Lyon 1, Villeurbanne, F-69622, France
}

References

1. Brough PA, Barril X, Borgognoni J, Chene P, Davies NGM, Davis B, Drysdale MJ, Dymock B, Eccles SA, Garcia-Echeverria C, Fromont C, Hayes A, Hubbard RE, Jordan AM, Jensen MR, Massey A, Merrett A, Padfield A, Parsons R, Radimerski T, Raynaud FI, Robertson A, Roughley SD, Schoepfer J, Simmonite H, Sharp SY, Surgenor A, Valenti M, Walls S, Webb P, Wood M, Workman P, Wright L: Combining Hit Identification Strategies: FragmentBased and in Silico Approaches to Orally Active 2-Aminothieno[2,3-d] pyrimidine Inhibitors of the Hsp90 Molecular Chaperone. J Med Chem 2009, 52:4809-4809.

2. McCoy MA, Wyss DF: Alignment of weakly interacting molecules to protein surfaces using simulations of chemical shift perturbations. J Biomol NMR 2000, 18:189-198.

3. Cioffi M, Hunter CA, Packer MJ, Spitaleri A: Determination of ProteinLigand Binding Modes Using Complexation-Induced Changes in $1 \mathrm{H}$ NMR Chemical Shift. J Med Chem 2008, 51:2512-2517.

4. González-Ruiz D, Gohlke H: Steering Protein-Ligand Docking with Quantitative NMR Chemical Shift Perturbations. J Chem Inf Mod 2009, 49:2260-2271.

doi:10.1186/1758-2946-6-S1-P18

Cite this article as: Brink et al.: Fragment docking supported by NMR shift perturbations. Journal of Cheminformatics 2014 6(Suppl 1):P18.

\footnotetext{
Publish with ChemistryCentral and every scientist can read your work free of charge

"Open access provides opportunities to our colleagues in other parts of the globe, by allowing anyone to view the content free of charge."

W. Jeffery Hurst, The Hershey Company.

- available free of charge to the entire scientific community

- peer reviewed and published immediately upon acceptance

- cited in PubMed and archived on PubMed Central

- yours - you keep the copyright

Submit your manuscript here:

http://www.chemistrycentral.com/manuscript/

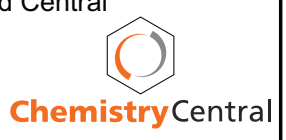

